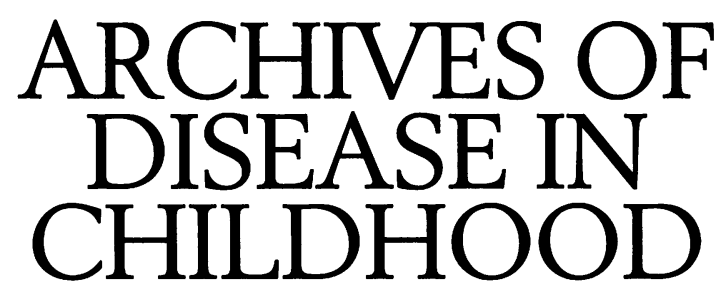

The fournal of the British Paediatric Association

\title{
Annotations
}

\section{Divorce and marital strife and their effects on children}

Divorce and marital strife stand alongside other environmental contributors to psychopathology in children: for example physical and psychiatric illness in the family, death of a parent, failure of parental attachment, etc. Clinicians take many such factors into account in their work with troubled and troublesome children in an attempt to tease out the factors central to the presenting problems in individual cases.

One in three marriages in the UK ends in divorce. One in five to six children under the age of 16 is affected. Divorce sets in motion a chain of events that affect the family irreversibly. These events are accompanied by short term psychological reactions in children which, in over one third of cases of children without previous psychological problems, have long term developmental effects akin to those resulting from traumatic experiences. 'The secure, protective setting of the family, desirable for development, is disrupted or smashed, producing in children and adolescents anger that may last for years, a loss of trust in parents, feelings of intense guilt, and a determination to avoid divorce themselves at all costs, which may interfere with the ability to establish long term relationships in adulthood, and affect their attitudes towards their own children. These effects may be mitigated by good experiences of family relationships after divorce and by psychotherapy. ${ }^{2}$

We cannot say in general whether children fare better when parents stay together in chronic conflict or when their parents divorce. Indeed, divorce itself cannot easily be distinguished from a host of associated and sequential circumstances: marital conflict (including violence and sexual acting out), separation (involving loss or partial loss of a parent), changed social and financial circumstances, single parenthood, ongoing court battles over maintenance and access, reconstituted families (bringing one or two step-parents and possibly step-siblings into the picture, and eventually children of the new unions). Thus, while the legal procedure of divorce takes place over a limited period, socially and emotionally the process is an extended one. From the child's point of view, divorce could usefully be conceptualised as a potential cumulative trauma-that is, the effect derives from a series of events rather from a single experience.
This approach raises the need for improved understanding of the interaction between family circumstances and the course of child development. Secondly, the prevalence of divorce itself testifies to a change in the nature of 'the family' in our society. The expectations of children whose families remain intact are affected by their contact with peers who have divorced parents. ${ }^{2}$

\section{Research perspective}

This annotation draws heavily upon a review of research by Wallerstein ${ }^{2}$ and the writing of Hodges. ${ }^{3}$ All the research cited has been conducted in the USA, mostly with middle class white families. Clinical experience suggests that the outcomes are applicable to the UK for the similar group of families.

A growing body of research and clinical evidence concludes that the effects of divorce are long lasting and carry over into the partnerships formed in adulthood by the children of divorce. Chronic conflict between divorced parents has been identified as a major stress upon children, and the parents' ability to reduce the children's exposure to such conflict seems to be helpful. We cannot say whether high conflict within marriage is more or less harmful than conflict after divorce in its effects upon children. One could argue that the overt exposure to conflict is reduced if the parents are apart, but disputes over access frequently place the children at the core of the fray. The extent to which the children are exposed to parental conflict, are actively recruited into it by the parents, or involve themselves in it by taking sides, may prove to be the central factors rather than the divorce itself. On the other hand divorce brings with it the host of sequelae mentioned above. Research has focused on distinguishing between the influence of the various factors and their effects upon children.

At the breakdown of the marriage, children have often spent years in homes where they felt unsupported by parents and subject to parental conflict. ${ }^{45}$ This research finds that child rearing is a major area of conflict in these families. It is not clear whether this represents a displacement of marital conflict, a convenient area for the expression of these conflicts, or a primary cause of marital conflict. ${ }^{2}$ 
Similarly the period immediately after divorce is characterised by strained parent-child relationships for 4 year olds, including high irritability, a steep decline in parental attention to the children's needs, and general disarray and a failure of discipline. ${ }^{6-10}$ Wallerstein's 15 year study indicates that many of these children will still be suffering from the ill effects when they enter adolescence. ${ }^{1} 2^{11-16}$

Johnston et al researched the children who are the subject of ongoing conflict between separated parents. ${ }^{17-19}$ Mediation had failed to resolve the disputes. The children were exposed to verbal and physical abuse between the parents, and were made victims or allies in the parental disputes. The younger children tended to be inhibited and anxious, while the older ones became aggressively involved in the parental conflict. They seemed both highly anxious and to want continued contact with both parents. They tended to feel responsible for the difficulties and helpless and vulnerable, and that any change would make things worse. Four and a half years after separation, children subject to joint custody orders that conflicted with the wishes of one or both parents were more depressed and withdrawn than others in sole custody.

Adolescents' experience of being caught in the middle was studied by Buchanan et al. ${ }^{20}$ This was associated with high level of parental discord and with depression, anxiety, and deviance among the young people. There is an experience of having no safe place and of being exploited by those who should provide care and protection.

This raises questions about the advisability of continued parental contact in such cases; see the large scale study by Furstenberg et al. ${ }^{21-24}$ Children of divorced parents and parents in high conflict were compared with children from low to moderate conflict partnerships. The children of divorce performed worse in respect of problem behaviour, academic performance, and psychological distress. Twenty three per cent had not seen their fathers for five years. However those who had not seen their fathers for five years seemed to perform better than those who had seen their fathers more recently. The authors did not feel that there was evidence to support interventions promoting paternal contact apart from financial support.

A national long term study of children in schools indicated consistent differences between children of divorced and intact families. ${ }^{25-27}$ Socially, behaviourally, and academically the children of intact families were doing better. Only the academic performance was associated with lower income in the divorced group. A number of researchers have found that children of divorce are more likely to divorce during their own adulthood than the children of intact families. ${ }^{28-31}$ Glenn et al found that the effects of experiencing parental divorce in childhood persisted significantly into adulthood and that these effects were consistently negative. ${ }^{28} 3233$

Children in Wallerstein's research were found to be worse 12-18 months after the divorce than when interviewed at the time. ${ }^{15}$ They had been affected by a sudden announcement by the parents, by a sudden departure, by the parents' self preoccupation and unhappiness experienced as a lack of attention, the loss of emotional, physical and financial security, the loss of hope. Sometimes they had retreated into self care. Five years after divorce, one third of the children were still worse. Most children still wanted their parents to get back together, and had little sympathy for their parents' actions. One third found themselves at the centre of continuing bitter disputes between the parents.

Wallerstein's findings indicate simultaneous processes at various levels: individual, familial, and social. The family break-up unleashed the love, hate, and sexual jealousy previously contained, and the children witnessed violence and sexual acting out by the parents. The children felt that their parents had failed. There were changes of home and school, and often a drop in financial status. Social supports tended to fall away, in contrast to other family crises such as illness or bereavement.

Wallerstein comments that the prolonged dependency of the young in our species makes the family the protective and nurturing structure during the period of maturation. Parental divorce is taken personally by the children. They react with rage and helplessness. They feel to blame, and, coincidentally, the arrival of children is often the start of parental discord. Children worry about losing contact with their parents. They need to think of a mutually affectionate relationship between their parents. However bad the marriage, children usually regard divorce as a loss. Most children do not see both parents recover.

Wallerstein draws attention to the different and complementary nature of the conceptual frameworks organising the research. ${ }^{2}$ She calls these the stress-copingvulnerability model (used for instance by Hetherington) and the psychoanalytic-clinical perspective (employed by Wallerstein). The former seeks to identify the stress, vulnerability, and protective factors in the child's constitution and environment to account for differences in coping. The latter identifies impediments to children's achievement of developmental tasks in the sphere of emotional development and relationships, using object relations theory. ${ }^{34}$ Thus Wallerstein, for example, identifies the internalisation of a successful parental relationship as the basis for establishing intimate, trusting relationships with the opposite sex. The internalisation of a failed relationship may be modified by subsequent experiences of parental remarriage, a good experience of parenting, a good marriage, or by psychotherapy.

\section{Implications of research for clinical and legal practice}

Hodges draws out the practice implications of research for professionals in the field concerned with offering advice, mediation, counselling, and treatment to children and families, or with advising on decisions about custody and access. $^{3}$

He suggests that keeping the family together for the sake of the children is ill advised. The ill effects upon children can be reduced by discussion and explanation, in a way that helps the children understand what is happening, and reassures them that they are not to blame. It is helpful if life changes are kept to a minimum for the children. He advises that children be kept out of parental disputes, are not allowed to become go-betweens or confidants for the parents, nor to adopt a parenting role towards parents. Prolonged uncertainty as in repeated parental separations and reconciliations are unhelpful. Children benefit from permission to have ambivalent feelings towards their parents and need to accept the limitations on their own ability to influence parental decisions about the marriage.

Counselling and mediation can help parents towards these goals. Counsellors should have an eye to inequality between the parents in their negotiating power, and to possible psychological pressure placed on children by parents. Mediators and counsellors are advised of the dangers of embroilment in legal disputes, and the importance of clarity around the boundaries of confidentiality.

Hodges draws attention to the fact that a parent's wish for custody can derive from attachment, but also from the wish for control or revenge, or a wish to compensate for the parent's own childhood experiences. Likewise, he warns against reliance upon children's own choice of carer, which may be based upon negotiating deals about bedtimes etc. 
(Under the 1989 Children Act, children's views do have to be taken into account but not necessarily taken literally.)

Hodges recommends frequent contact with the noncustodial parent where parental conflict is low and the pathology of the non-custodial parent is low, and where there are no child protection considerations. Frequent access in cases of high conflict and high parental pathology is seen as not in the child's best interests. He also warns of children's own contribution to disputes over access.

On the subject of reconstituted families, Hodges suggests among other things that children be allowed to develop a relationship to the step-parent at their own pace. It is ill advised for new partners to assume a disciplinary role before a relationship of affection is established.

\section{Clinical perspective}

Reactions to divorce and marital strife produce the same range of symptoms and behavioural phenomena as other forms of stress in childhood, and are frequently a factor even when not overtly part of the presenting problem. The children who present to child mental health services specifically for help with reactions to marital strife or divorce are a selected sample, including those whose parents are especially concerned for their welfare, those whose parents are seeking support in disputes over custody and access, and children who cause concern to parents, schools, social workers, and doctors because of severe reactions. These may take the form of a child's chronic anger with one parent, refusal to accept a step-parent, clinging behaviour, excessive anxiety about arguments, fears of violence or loss, low self esteem and fears of abandonment, insecurity about personal identity in adolescence related to a lost or absent parent. Often the children referred are at the heart of battles over access in which there is no such thing as safe neutrality. In such instances, every aspect of their lives may be invaded by partisan considerations, whether it be school, or medical or psychological treatment, and the child and family mental health services may be unable to help until a reduction in the level of conflict makes effective intervention possible.

A variety of interventions (family, group, individual, parental, cognitive, behavioural, psychodynamic) is possible depending on need, patient preferences, and local resources. Interventions probably have the best chance of success where the consent of both parents is obtained, and where feasible goals are set which relate to the alleviation of the presenting problems. It is also helpful if treatment can be constituted as an area of intervention distinct from legal proceedings. This allows the potential for exploration which is usually impossible where either parents or children are determined to use treatment to force a particular outcome.
Department of Child Psychiatry,

Lanesborough Wing, St George's Hospital,

Blackshaw Road,

London SW17 OQT

1 Wallerstein JS, Blakeslee S. Second chances. London: Bantam Press, 1989.

2 Wallerstein JS. The long-term effects of divorce on children: a review. $\mathcal{F} \mathrm{Am}$ Acad Child Adolesc Psychiatry 1991; 30: 349-60.

3 Hodges WF. Interventions for children of divorce. New York: John Wiley, 1991.

4 Block JH, Block J, Gjerde PF. The personality of children prior to divorce. Child Dev 1986; 57: 827-40.

5 Block J, Block JH, Gjerde PF. Parental functioning and the home environment in families of divorce. $\mathcal{F} \mathrm{Am}$ Acad Child Adolesc Psychiatry 1988; 27: 207-13.

6 Hetherington EM, Cox M, Cox R. The aftermath of divorce. In: Stevens JH $\mathrm{Jr}$, Matthews M, eds. Mother-child, father-child relations. Washington, DC National Association for the Education of Young Children, 1978: 149-76.

7 Hetherington EM. Stress and coping in children and families. In: Doyle A, Gold D, Moskowitz DS, eds. Children in families under stress. New directions for child development No 24. San Francisco: Jossey-Bass, 1984:7-33.

8 Hetherington EM, Arasteh J, eds. The impact of divorce, single parenting and step parenting on children. Hillsdale, NJ: Lawrence Erlbaum, 1988.

9 Hetherington EM. Coping with family transitions. Child Dev 1989; 60: 1-14.

9 Hetherington EM. Coping with family transitions. Child Dev 1989; 60: 1-14. Am Psychol 1989; 44: 303-12.

11 Wallerstein JS. Children of divorce: preliminary report of a ten-year follow-up of young children. Am $\mathcal{F}$ Orthopsychiatry 1984; 54: 444-58.

12 Wallerstein JS. Children of divorce: preliminary report of a ten-year follow-up of older children and adolescents. $\mathcal{F}$ Am Acad Child Psychiatry 1985; 24: 545-53.

13 Wallerstein JS. Women after divorce. Am $\mathcal{f}$ Orthopsychiatry 1986; 56: 65-77.

14 Wallerstein JS. Children of divorce: report of a ten-year follow-up of early latency-age children. Am f Orthopsychiatry 1987; 57: 199-211.

15 Wallerstein JS, Kelly JB. Surviving the break-up. New York: Basic Books, 1980.

16 Wallerstein JS, Corbin S. Daughters of divorce. Am F Orthopsychiatry 1989; 59: 593-604.

17 Johnston JR, Campbell LEG. Impasses of divorce. New York: The Free Press, 1988.

18 Johnston JR, Campbell LEG, Mayes SS. Latency children in post-separation and divorce disputes. F Am Acad Child Psychiatry 1985; 24: 563-74.

19 Johnston JR, Kline M, Tschann JM. Ongoing post-divorce conflict. Am f Orthopsychiatry 1989; 59: 576-92.

20 Buchanan CM, Maccoby EE, Dornbusch SM. Caught between parents adolescents' experience in divorced homes. Child Dev 1991; 62.

21 Furstenberg FF Jr, Nord CW. Parenting apart. fournal of Marriage and the Family 1985; 47: 893-904.

22 Furstenberg FF Jr, Seltzer JA. Divorce and child development. In: Adler PA, Adler P,eds. Sociological studies of child development. Vol 1. Greenwich, CT: JAI Press, 1986:137-60.

23 Furstenberg FF Jr, Peterson J L, Nord CW, Zill N. The life course of chilfren of divorce. American Sociological Review 1983; 48: 656-68.

24 Furstenberg FF Jr, Morgan SP, Allison PD. Paternal participation and children's well-being after marital dissolution. American Sociological Review 1987; 52: 695-701.

25 Guidubaldi J. Differences in children's divorce adjustment across grade level and gender. In: Wolchik S, Karoly P, eds. Children of divorce. Lexington, MA: Lexington Books, 1988:185-231.

26 Guidubaldi J, Perry J D, Nastasi BK. Assessment and intervention for children of divorce. In: Vincent JP, ed. Advances in family intervention assessment and theory. Vol 4. Greenwich, CT: JAI Press, 1987: 33-69.

27 Guidubaldi J, Perry J D, Nastasi BK. Growing up in a divorced family. In: Oskamp S, ed. Annual review of applied social psychology. Beverly Hills, CA: Sage Publications, 1987: 202-37.

28 Glenn ND, Shelton BA. Pre-adult background variables and divorce. fournal of Marriage and the Family 1983; 45: 405-10.

29 Kulka RA, Weingarten $H$. The long-term effects of parental divorce in childhood on adult adjustment. Fournal of Social Issues 1979; 35: 50-78.

Mueller CW, Pope H. Marital instability. Fournal of Marriage and the Family 1977; 39: 83-93.

31 Pope H, Mueller CW. The intergenerational transmission of marital instability. Fournal of Social Issues 1976; 32: 49-66.

32 Glenn ND, Kramer KB. The psychological well-being of adult children of divorce. Fournal of Marriage and the Family 1985; 47: 905-12.

33 Glenn ND, Kramer KB. The marriages and divorces of the children of divorce. fournal of Marriage and the Family1987; 49: 811-25.

34 Wallerstein JS. Children of divorce: the psychological tasks of the child. $\mathrm{Am}$ f Orthopsychiatry 1983; 53: 230-43.

\section{Bone marrow transplant for sickle cell disease - an update}

Bone marrow transplant (BMT) offers a cure for sickle cell disease and experience is increasing relating to outcome and problems. Sickle cell disease is a family of recessively inherited $\beta$-globin disorders, of which sickle cell anaemia (SS) is generally the most severe. The severity of the disease is very variable, not only from patient to patient but also in any single person over time. ${ }^{1}$ Our knowledge respecting the disease has advanced since the initiation of the collaborative study of BMT for SS from Seattle, USA, and the definition of UK criteria for BMT by the British Paediatric Haematology Forum (BPHF), a subcommittee of the British Society for Haematology. It is, therefore, timely to review the role of BMT in sickle cell disease.

\section{Criteria for selection}

Despite the radical suggestion that any SS child with an HLA compatible sibling should be transplanted in infancy, ${ }^{2}$ which we do not support, we believe that our 